\section{EDUCATION}

Research, Innovation and Solutions on-line ${ }^{(2)}$
PSYCHOLOGY

I+D+i

\section{Electronic Journal of Research}

in Educational Psychology

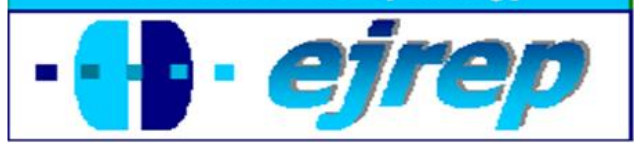

Editorial EOS

\title{
Assertive Skills and Academic Performance in Primary and Secondary Education, Giftedness, and Conflictive Students
}

\section{Montserrat Marugán de Miguelsanz, Miguel Angel Car- bonero Martín, M$^{\mathrm{a}}$ Marcela Palazuelo Martínez}

Grupo de Excelencia de Psicología de la Educación (GIE 179 de Castilla y León). Universidad de Valladolid

Spain

Correspondencia: Montserrat Marugán de Miguelsanz. Facultad de Educación y Trabajo Social. Paseo de Belén, $n^{\circ}$ 1. 47011. Valladolid. España. E-mail: mmarugan@psi.uva

(C) Education \& Psychology I+D+i and Editorial EOS (Spain) 


\begin{abstract}
Introduction. This study explores the level of assertiveness in various samples of students from Primary and Secondary Education. With the data obtained, on the one hand, we analyzed the relation between assertiveness and academic performance and, on the other, we verified whether students who are excluded from the norm, either because of their intellectual giftedness or because they display disruptive behavior in the classroom, obtain different scores in assertiveness. The study analyzes the relation between the excess or deficit of assertive skills and academic performance and, in turn, seeks to verify whether more rebellious students, from an academic viewpoint, or students who are intellectually gifted score differentially from the rest of the students of their level of assertion.
\end{abstract}

Method. A sample of Primary and Secondary Education students from Spanish public centers, whose academic performance was normally distributed, was used. Students from Primary Education, selected for their high intellectual giftedness and good academic performance, who participated in a cognitiveaffective development program, and a group of students from Secondary Education, integrated in Compensatory Education units, who were highly conflictive and who achieved very poor academic results, were analyzed. Self-rated assertiveness questionnaires were administered for comparison with the mean school grades and the number of subjects flunked.

Results. A statistically significant negative correlation was obtained between the variables assertiveness and academic performance in the diverse samples analyzed. The data support the hypotheses proposed in the study. Significant negative correlations were obtained between performance in Natural Sciences, Social Sciences, Mathematics, Technology and the variable assertiveness; the correlation was lower when Language was also taken into account, and nonexistent when correlated with English.

Discussion. From this study, it is concluded that, although an assertive deficit can act like a variable that predisposes towards academic failure, as it hinders students' interactions with teachers and classmates, a deficient assertive or passive dependent pattern can also generate behaviors that lead to very satisfactory academic results. However, the excess of this social skill or students' erroneous selfperception can originate a form of academic failure.

Keywords. Assertiveness, academic performance, social skills, conflictive students, intellectual giftedness. 


\section{Capacidades para la asertividad y rendimiento académico en la educación primaria y secundaria, altas capacidades y alumnos conflictivos}

\section{Resumen}

Introducción. Este estudio explora el nivel de asertividad en diferentes muestras de estudiantes de Primaria y Secundaria. Analiza la relación entre el exceso o déficit de habilidades asertivas y el rendimiento académico y, a su vez, busca comprobar si los alumnos más rebeldes, desde el punto de vista escolar, o los alumnos con alta dotación intelectual puntúan de forma diferencial al resto de estudiantes de su nivel en esta variable.

Método. Se trabajó con una muestra de estudiantes de Educación Primaria y de Secundaria de centros públicos españoles, cuyos rendimientos escolares se distribuían de forma normalizada. Se realizaron también los análisis, con alumnos/as de Educación Primaria seleccionados por su alta dotación intelectual y buen rendimiento académico, inmersos, además, en un programa de desarrollo cognitivoafectivo y con un grupo de estudiantes de Secundaria, integrados en unidades de Educación Compensatoria, altamente conflictivos y con resultados escolares muy negativos. Se administran cuestionarios de autoevaluación de la asertividad para compararlos con las medias de las calificaciones escolares y número de suspensos.

Resultados. Se obtiene una dependencia inversa estadísticamente significativa entre las variables asertividad y rendimiento académico en las diferentes muestras analizadas. Datos que avalan las hipótesis planteadas en el estudio. Se presentan correlaciones inversas y significativas (0.01) entre rendimiento en Ciencias Naturales, Ciencias Sociales, Matemáticas, Tecnología y la variable asertividad, de índole más baja cuando consideramos el lenguaje $(0,05)$, e inexistente cuando correlacionamos con el inglés.

Discusión. De este estudio se puede deducir que, si bien el déficit asertivo puede actuar como una variable predisponente hacia el fracaso escolar, ya que dificulta al alumno las interacciones con profesores y compañeros, pensamos que un patrón asertivo deficitario o pasivo dependiente puede generar conductas que provoquen resultados escolares muy satisfactorios. Por otra parte, el exceso de esta habilidad social o su autoconcepción errónea puede originar una forma de fracaso escolar.

Palabras clave. Asertividad, rendimiento académico, habilidades sociales, estudiantes conflictivos, superdotación. 


\section{Introduction}

Reference to social competence implies assertiveness, an important social skill that has a singular manifestation in the school setting. There are many situations at school where the lack or excess of this skill generates many difficulties for the teacher and also for the students. Examples are: children who depend excessively on their teachers' or classmates' judgments or, at the opposite extreme, who only follow their own rules; students who spend a lot of time alone because they do not dare to join a game; children who are brusque because somebody took their pencil or children who never know how to refuse the constant self-serving petitions of some classmates; students who have upsetting psychosomatic symptoms because of their fear of speaking in public or being called to the blackboard (what will the others say if I make a mistake?). The detection and early correction of these situations by teachers will be a key factor in students' future social integration.

A better definition of students' assertive manifestations or of their possible repercussions in essential aspects of learning and behavior would facilitate the teachers' better comprehension of the social factors that occur in the classroom. In the framework of the social skills construct, assertiveness is defined as interpersonal behavior that allows the direct expression of one's feelings, without cognitive distortions or anxiety, combining verbal and nonverbal components, and the defense of one's rights, while respecting those of others (Ames \& Flynn, 2007; Caso \& Hernández, 2007; Dietz, Jennings \& Abrew, 2005; GoldbergLillehoj; Harman, Hansen, Cochran, \& Lindsey, 2005; Monjas \& González, 2000; Riso, 1988; Swanson, 2007; Trianes, Blanca, García, Muñoz, \& Fernández, 2007; Turner, 1992). According to Carrobles (1986), such behavior is not an individual's stable and general trait; a person may be sufficiently assertive in some situations and inefficient or even inhibited in others. Nevertheless, there is evidence of a personal tendency to behave according to certain prototypes in one's social interactions, such as assertive or socially skilled behavior, passive behavior, and at the other extreme, aggressive behavior.

Caballo (1993) explains that assertive individuals usually cope well in their interpersonal relations, are satisfied with their social life, and are confident that they can change when they need to. However, aggressive people, when defending their personal rights - which they usually do in a domineering way-transgress ethical norms and do not care whether others' 
rights are disregarded. At the other extreme, students who display passive behavior are incapable of expressing their thoughts and feelings to others, and if they do so, they are selfdefeating and behave with a lack of confidence. This causes them to be ignored by others, which, as a result, decreases their self-esteem. Caballo also states that an unassertive person, in addition to showing a lack of self-respect, also displays some lack of confidence in others' capacity to deal with frustrations, responsibilities, etc. Ultimately, they hope to appease others and avoid conflict. In his bidimensional model, Del Greco (1983) refers to different forms of implicit and explicit coercion in these patterns. Assertion is openly expressed, without exerting coercion on the other person, whereas aggressive behavior is openly, but coercively, expressed. However, another form of coercion is that displayed is passive aggression, in which the behavior is indirectly expressed, while attempting to control the other person indirectly or subtly. Nonassertion implies either a lack of expression of the behavior or else indirect expression, but without intimidating the other person.

To paraphrase De la Peña, Hernández \& Rodríguez (2003) and Rodríguez \& Paíno (1994), assertion implies empathy and moral values in order to understand different points of view and to articulate, at the right time, the diverse skills required by the situation. According to these authors, the assertive student sought by the educator is one who does not act tough when facing weaker classmates, nor weak when dealing with the tough ones, but instead one who maintains a serene fortitude when faced with others' incoherence, immaturity, and egoism.

Academic performance is one of the goals of the teaching-learning process pursued by educational authorities, teachers, parents, and students (Fenández \& Gutiérrez, 2009; González, Saura, Rodríguez \& Linares, 2010). For this reason, we have paid attention to the search of possible predictors of the future performance (Wilson \& Hardgrave, 1995). Academic performance is the main indicator of the cognitive enrichment, aptitudes, skills, abilities, and strategies with which students deal with the processes of study. Although it is not the only sign of students' achievement, the grades in the diverse subjects are the most frequently employed operational measurement.

Currently, there is no doubt that students with assertive competence will develop easier in the school setting, because this setting will allow them to deal adequately with interpersonal social situations. There is much bibliography about social skills and emotional intelli- 
gence in the school setting (Castejón \& Pérez, 1998; Jiménez \& López, 2009; Stephanou, 2011), and, to a lesser extent, about the specific competence of assertiveness (Garrido, Ortega, Escobar \& García, 2010). However, the studies conducted do not explicitly express the repercussions of an adequate level of assertiveness or the result of assertiveness training on academic performance as assessed by academic grades (Kamalanabhan, 1998; Rajendran \& Kaliappan, 1991). In numerous studies, no significant correlations were found (García, 2005; Caso \& Hernández, 2010) had to eliminate the variable assertiveness from an explanatory model of variables that influenced academic performance of students between ages 15 and 23 years, which they tested with structural equations modeling. In the university area, Velásquez, Montgomery, Montero, Pomalaya, Dioses \& al. (2008) found no association between assertiveness and academic performance, or with gender or in the diverse faculties studied.

\section{Objetives and hypotheses}

In the mentioned framework, the present study pursued the following goals: (a) To assess the level of assertiveness of a sample of students from the following segments: Primary Education, Secondary Education, highly gifted students with good academic performance from Primary Education, and conflictive students with very poor academic results from Secondary Education; (b) To determine whether the excess or lack of assertive skills has any relation with academic performance as assessed by the school grades; and (c) To test whether the more rebellious students, from the school viewpoint, score differentially from the rest of the students in their level of assertiveness.

We tested the following hypotheses: (a) students from Primary and Secondary Education who achieve very high school grades will score low in assertiveness; therefore, gifted students with very high grades will also score low in assertiveness; (b) students from Secondary Education who display disruptive and conflictive behavior in the classroom and whose academic performance is poor will obtain higher scores in the variable assertiveness. 


\section{Method}

\section{Participants}

Three types of population were used in this investigation:

1. Sample of students from Primary and Secondary Education: 160 students, 65 students from third and fourth grade of Primary Education and 95 students from first and second grade of Secondary Education (Spain). In these courses, the students with different academic performance and capacity are randomly distributed.

2. Sample of students with disruptive behavior and poor academic performance: 20 students from second grade of Secondary Education of public institutes. They present continued academic failure and problematic behavior. They attend a classroom of compensatory education, and only join their classmates to study the areas of Physical Education, Music, and Technology. Despite their very high rate of flunked subjects, they have the intellectual capacity to study, but they are incapable of applying the implicit study strategies: motivation, attention, following instructions, etc.

3. Sample of gifted or high-capacity students: 23 students characterized as having high capacities with very good academic performance, from third and fourth grade of Primary Education in various public and concerted centers of Valladolid (Spain).

\section{Instruments}

To assessment the variable assertiveness, we used the following self-rated instruments: The Children's Assertive Behavior Scale (CABS), developed by Michelson, Wood, and Kazdin (1987). Originally, this scale was validated by authors with 90 students from fourth, fifth, and sixth grade of Primary Education and has an internal consistency index of .80. This scale can be used in two ways: a) as an "other-report" about the children's behavior, b) as a self-report, which is the modality used in this investigation. Respondents are pressented with 27 situations that propose topics such as how to make and receive compliments, criticize and receive criticism, ask for help and lend objects, accept responsibility, help others, start conversations, and follow orders. The items have 5 response options, and the students choose the one that best reflects their habitual social behavior. This measurement ranges on a continuum from very inhibited or passive behaviors, partially passive behaviors (negative scores), to as- 
sertive behaviors (mid-score, 0), to partially aggressive behaviors, to very aggressive behaviors (positive and high scores). The characteristics are more or less marked depending on the distance from 0 .

Scale for the Assessment of Assertiveness (ADCA-1) of García and Magaz (1994). This scale was used to assess the sample of students with disruptive behavior and poor academic performance was also studied with. According to the authors, this test was designed to appraise the degree to which individuals interact with each other, using a system of assertive cognitions that can modulate assertive instrumental and emotional behavior.

It includes two subtests, one assesses the concept of "self-assertiveness" (SA), that is, the assertive rights that people grant themselves; the other subtest assesses "heteroassertiveness" (HA), which detects the degree to which a person grants others basic assertive rights. It identifies various styles of social interaction: aggressive, passive-dependent, average assertiveness, deficient assertiveness, and high assertiveness. According to the authors, people with a passive -dependent style score high in HA and low in SA; they behave with a lack of respect for their own rights in benefit of others. People with an aggressive style (the opposite case), score low in HA and high in SA: there is a lack of respect for other's rights in their own benefit. The average scores refer to people who accept their own idiosyncrasies as well as those of others. High or low scores in both scales indicate a either high or a deficient level in these variables. However, when analyzing the relations between the two variables assessed by the test to obtain behavior patterns, the behavioral pattern is considered more aggressive as the SA scores rise (percentile over 50) and the HA scores decrease.

The variable academic performance was operationalized by means of the school grades, taking into account only the grades in the curricular subjects that establish more performance differences. For the sample of students with disruptive behavior, we also used the number of subjects flunked, taking into account the ten curricular subjects.

\section{Procedure}

The tests were administered by the teachers during the usual classes and the normal schedule, as reassuring element and to a better control of variables. They were administered to the participants at mid term, as this was considered the best time, when there was no ten- 
sion due to the beginning or the end of the course. We obtained the school grades from the secretariat. It was controlled that students do not take any exam in order to avoid a loss of attention. Instruments were chosen by their excellent fitness to the selected ages, and were collectively applied.

\section{Data analysis}

The study is based in a descriptive, analytical and transversal design. Analyses of correlational and percentage type have been developed. Assertiveness was the independent variable; school level (Primary and Secondary Education), high intellectual capacity (giftedness) and high academic performance, and problematic behavior and poor academic performance were assigned variables; and academic performance (school grades) was the dependent variable.

\section{Results}

Assertiveness and academic performance in the sample of primary education students with normal performance

According to the results (Table 1), the students with the highest mean in performance (range 8.1-10), obtained a mean assertiveness score of -3.75 in the Children's Assertive Behavior Scale (CABS), much lower than level 0 (the optimum level according to the test). Likewise, values of the mean in performance between 6.1 and 8 are also connected with a low assertiveness score (-3.10). However, this score is lower (-1.33) for mean in performance values ranged between 2.1 and 4. No student was assigned to the lowest interval of school grades. As the primary students had generally achieved higher grades than the secondary students, it is difficult to compare them; the number of subjects flunked by primary students was almost insignificant.

The primary students tended to self-rate their assertiveness lower than did the secondary students: $67.69 \%$ of the sample had scores lower than around -1 (Table 2), which did not occur in the secondary students' self-assessment. This could be a possible indicator of the concomitance of age and assertiveness. 
Table 1. Mean scores obtained in school grades and results in the Children's Assertive BehaviorScale (CABS), indicating the percentages of Primary students in the sample

\begin{tabular}{cccccc}
\hline Mean school grade & $0-2$ & $2.1-4$ & $4.1-6$ & $6.1-8$ & $8.1-10$ \\
Assertiveness score & & -1.33 & -3.15 & -3.10 & -3.75 \\
$\%$ students & 0 & $4.61 \%$ & $20 \%$ & $44.6 \%$ & $30.76 \%$ \\
\hline
\end{tabular}

Table 2. Percentage of Primary students with regard to the scores of the Children's Assertive Behavior Scale (CABS)

\begin{tabular}{cccccccc}
\hline Assertiveness & & & & & & & \\
scores & $(-8 \ldots)$ & $(-5,-6,-7)$ & $(-2,-3 .-4)$ & $(-1,0,+1)$ & $(+2+3+4)$ & $(+5+6+7)$ & $(+8 \ldots)$ \\
Percentages & $15.38 \%$ & $20 \%$ & $32.30 \%$ & $21.53 \%$ & $10.76 \%$ & 0 & 0 \\
\hline
\end{tabular}

Assertiveness and academic performance in the sample of secondary education students with normal performance

Upon analyzing the sample of secondary students with the Children's Assertive Behavior Scale (CABS), we observed that the Pearson correlation between the mean of the school grades in the diverse subjects of each student and their assertiveness score was negative and, although not very high (-.277), it was significant at the $1 \%$ confidence level. We note that, although the correlations between assertiveness, Natural Sciences, Social Sciences, Mathematics, and Technology were significant (between -.256 and -.296), there was no significant relation between assertiveness and English.

In this test, the students with mean grades between 8.1 and 10 obtained a mean assertiveness score of -3.89 points, much lower than level 0 (optimum level according to the test). And the students who achieved mean grades between 6.1 and 8 also obtained low mean scores in assertiveness (-2.92), whereas, at the opposite pole, the students who achieved grades between 0 and 2 points presented a mean score of 7 points in the CABS. These data could be an indication that both variables covariate inversely.

We also analyzed the possible dependence/independence of the variables assertiveness and academic performance by operationalizing the latter by the mean number of subjects flunked by each student. Although the Pearson correlation was not very high, it was positive $(r=.320)$ and statistically significant $(p=.01)$. That is, as the number of flunked subjects 
increased, the students seem to self-rate themselves as more assertive. The results in the extreme scores seem fairly clear; the students who flunked an average of 9 or 10 subjects selfrated themselves in assertiveness (CABS) with a very high score (mean of 6.08), whereas the students who flunked an average of 0-2 subjects obtained mean scores corresponding to an assertive deficit (-2.30 points).

Assertiveness and academic performance in the sample of secondary education students with disruptive behavior and poor academic performance

Upon analyzing this sample with the Children's Assertive Behavior Scale (CABS) (Figure 1), we verified that $49.50 \%$ of the participants self-rated their behavior as assertive (scores around 0 ), choosing $21.26 \%$ of the responses that are considered patterns with aggressive and very aggressive tendencies (12.02\% of the sample). Of the sample, $29.24 \%$ expressed inhibition or lack of self-confidence in their behavior, of whom $14.28 \%$ chose responses classified as very inhibited.

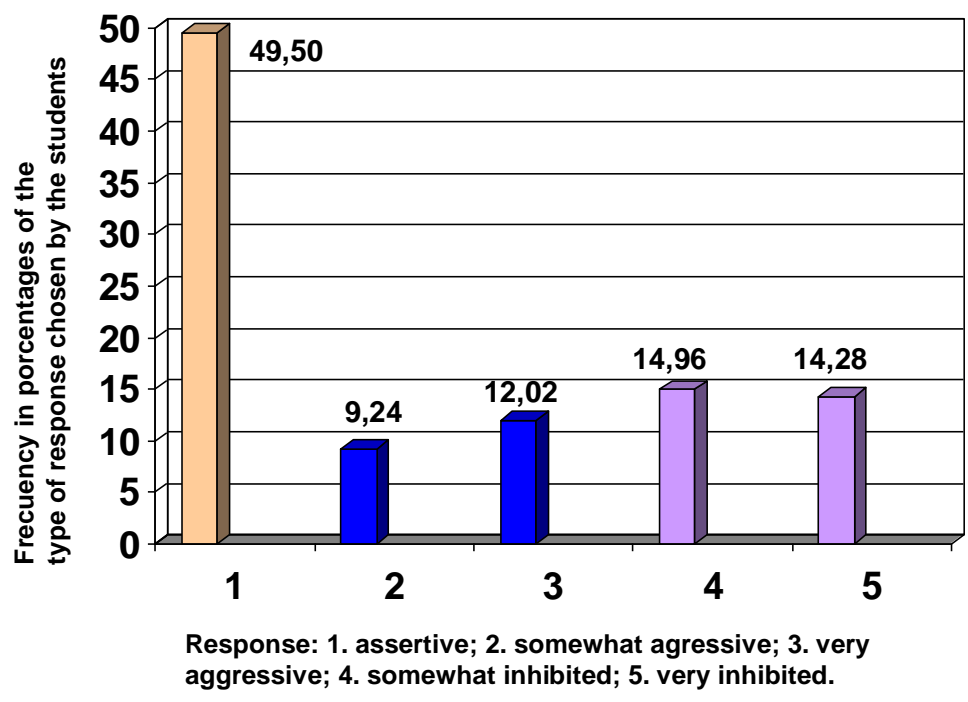

Figure 1. Results in the Children's Assertive Behavior Scale (CABS) of students with disruptive behavior and very low academic performance 
The results in the Scale for the Assessment of Assertiveness (ADCA-1) (Figure 2), show that $53.3 \%$ of the sample obtained scores exceeding percentile 80 in self-assertiveness, and $66.6 \%$ exceeded percentile 50 .

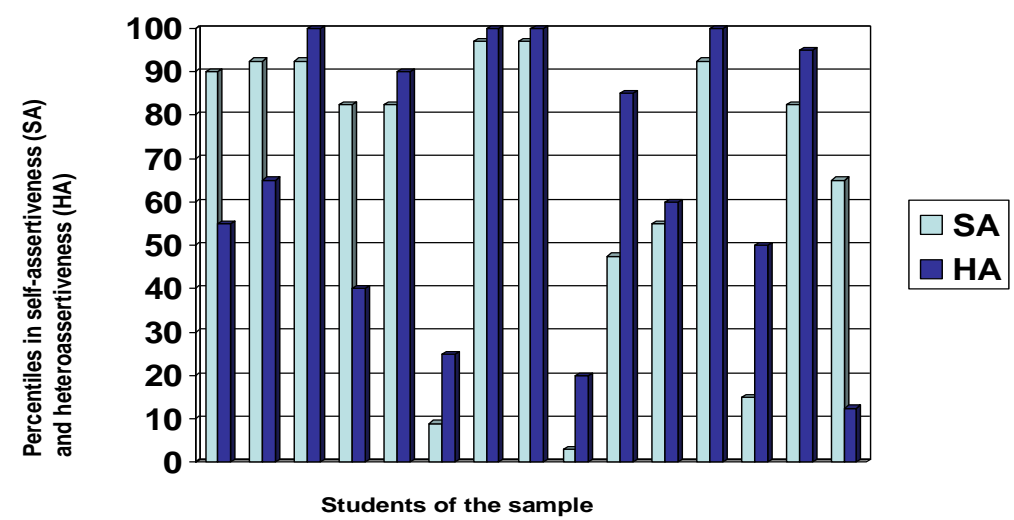

Figure 2. Results in the Scale for the Assessment of Assertiveness (ADCA-1) of students with disruptive behavior and poor academic performance

Assertiveness in the sample of gifted students with good academic performance in Primary

\section{Education}

The sample of primary students diagnosed as intellectually gifted had good academic performance and, according to their teachers, only two students displayed some "rebellious" behavior. In accordance with our comments about the results at this educational level, these students may also obtain lower assertiveness scores than students from Secondary Education.

Table 3 shows the results obtained in the Children's Assertive Behavior Scale (CABS). Of the sample, 30.4\% responded to assertive patterns (scores near 0), and a greater number of students obtained negative scores in the test $(47.8 \%)$, corresponding to behaviors of low assertiveness, assertive deficit, and passive-dependent patterns, compared with the percentage of students who obtained positive results $(21.7 \%)$ that indicate very assertive or aggressive patterns. 
Table 3.Percentage of the type of assertive response chosen by gifted students with good academic performance. In the Children's Assertive Behavior Scale (CABS)

\begin{tabular}{cccccccc}
\hline $\begin{array}{c}\text { Assertiveness scores } \\
\text { Percentage }\end{array}$ & $(-8 \ldots)$ & $(-5,-6,-7)$ & $(-2,-3 .-4)$ & $(-1,0,+1)$ & $(+2+3+4)$ & $(+5+6+7)$ & $(+8 \ldots)$ \\
\begin{tabular}{c} 
of students \\
\hline
\end{tabular} & $8,7 \%$ & $17,4 \%$ & $21,7 \%$ & $30,4 \%$ & $4,3 \%$ & $8,7 \%$ & $8,7 \%$ \\
\hline
\end{tabular}

\section{Discussion}

The results obtained with the four samples analyzed support the hypotheses proposed in this study and confirm previous works (Marugán, 2000; Marugán \& Román, 2004). The hypotheses posited that: (1) students from Primary and Secondary Education who achieve very high school grades will score low in assertiveness; hence, gifted students with very high grades will also score low in assertiveness; (2) students from Secondary Education who display disruptive and conflictive behaviors in the classroom and whose academic performance is poor will obtain higher scores in the variable assertiveness.

The results confirm that students from Primary and Secondary Education with very high school grades score low in assertive skills, and a very high percentage of the sample of gifted primary students also scored low in assertiveness. In contrast, the more problematic students with a high number of flunked subjects scored very high in assertiveness, and a high percentage of them tended towards aggressiveness.

Despite the fact that the analyses with all the samples present an acceptable correlational and negative tendency, the nature of these correlations requires a differential analysis. Wolpe's (1973) reference might be applied to the normalized sample of Primary and Secondary Education: he indicates that a common characteristic in the clinical history of people who need assertive training is that, during their early years, social obligations were excessively emphasized, which generated a feeling that other people's rights were more important that their own. A large amount of the highest scores in academic performance correspond to assertive deficits, which could be related to these students' higher vulnerability to social and academic pressure. This permeability to the demands "of the authorities" and "doing things right" would lead them to avoiding failure and attempting to perfect their academic results. 
Many students who try to pass all the subjects and achieve very good grades are under family and social pressure. Since early childhood, they are aware of the importance of their grades for their parents and relatives, and they have felt this to be an obligation. They have received many affective reinforcements for their behavior and, although they are convinced of the need to pass, many of them initially put out effort influenced more by their fear of others' reactions - especially those of the authorities - than by their own desires and preferences regarding their studies. This obligation turns into gratification over time, and study becomes their modus vivendi. In such a family environment of respect and admiration for everything related to school, less assertive or passive-dependent students are more vulnerable to others' opinions and to failure, which becomes a greater determination to stand out.

The percentage obtained in assertiveness by the sample of problematic students with very poor academic performance are very similar in both the scales used, more reliably revealing that the students of the sample self-rated their behaviors with a high degree of selfconfidence. These results are interesting, taking into account that this sector of students, who are studying in units of Compensatory Education, are strongly criticized by the people from their environment, who try to impose the norms of common sense and acceptance of the cultural and social setting surrounding them. The self-perceptions of these aggressive adolescents (or with high levels of assertiveness) and the assessment of their social competence are both biased, as diverse studies have noted (Trianes, Cardelle, Blanca, \& Muñoz, 2003; Salmivalli, Kaukiainen, Kaistaniemi, \& Lagerspetz, 1999). There are also works that indicate that this kind of students has difficulties being objective and impartial when decoding external stimuli (Dodge, Bates, \& Pettit, 1990; Dodge, Price, Coie, \& Christopoulos, 1990; Rodríguez \& Paíno, 1994).

The high level of assertiveness shown by the students with disruptive behavior contradicts the concept of empathy that is implicit in this construct. One of the possible negative results associated with excessively assertive or aggressive behavior could be feelings of guilt, but these students have a particular "lack of conscience," as well as a marked incapacity for empathy, or for the appropriate appraisal of their behavior. In effect, although they are very strict in their ethical criteria, classifying behaviors observed in other models as very aggressive and harmful, they may justify the same behaviors as "jokes" when they perform them. This defiant self-affirmation (derived from their negative experiences) may be one of the main sources of their problems with family, school, and social adaptation. 
To conclude, we summarize the following results:

We obtained a statistically significant inverse correlation between the variables assertiveness and academic performance (school grades) in a sample of students from Primary and Secondary Education. We also found a direct statistically significant correlation between the variable assertiveness and academic performance as assessed by the number of subjects flunked. Having flunked a large number of subjects corresponded to very high scores of assertiveness, especially when the number of flunked subjects was associated with problematic behaviors.

Both data support the hypotheses proposed in this study and confirm prior studies (Marugán, 2000; Marugán \& Román, 2004), in the sense that the more problematic students scored very high in assertiveness. It should be taken into account that this type of students also has the lowest grades and a large number of flunked subjects. Inverse and statistically significant correlations were obtained between the means of the subjects of Natural Sciences, Social Sciences, Mathematics, and Technology and the means in assertiveness, which is coherent with previous data), lower correlations when considering Language, and nonexistent when English is also correlated. These data, which are difficult to interpret, require more research.

From this study, it is concluded that, although an assertive deficit can act like a variable that predisposes towards academic failure, as it hinders the students' interactions with teachers and classmates (García \& Magaz, 1994), such deficient assertive or passive dependent patterns can also generate behaviors that lead to very satisfactory academic results. However, the excess of this social skill or students' erroneous self-perception of it can originate a type of academic failure.

This study has some limitations. Some suggested improvements for future investigations are: the assessment of assertiveness not only from the viewpoint of the subjects' selfperception--which may or may not coincide with their real competence--, the number of participants in the samples--which should be expanded--, and testing the results with more complex statistical analyses. Nevertheless, the results of the work contribute valuable information 
to understand educational practice, especially its influence on performance and on the possible improvement of primary and secondary students' behavior.

Future works might consider the assessment of assertive competence by an external evaluator, although this is highly problematic in very large samples. In any case, we expect to confirm the conclusions and extend the study to a broader sample in the sectors already examined, and also to include university students

\section{Acknowledgements}

This work was financed by the Junta of Castilla and Leon, Spain (GIE 179).

\section{References}

Ames, D. \& Flynn, F. (2007). What breaks a leader: the curvilinear relation between assertiveness and leadership. Journal of Personality and Social Psychology, 92(2), 307324.

Caballo, V. (1993). Manual de evaluación y entrenamiento de las habilidades sociales [Handbook of social skills assessment and training]. Madrid: Siglo XXl.

Carrobles, B. (1986). La práctica de la terapia de conducta: Teoría y método de aplicación para la práctica clínica [Practice of behavior therapy: Theory and application method for clinical practice]. Valencia, Spain: Promolibro.

Caso, J. \& Hernández, L. (2007). Variables que inciden en el rendimiento académico de adolescentes mexicanos [Variables that influence the academic performance of Mexican adolescents]. Revista Latinoamericana de Psicología, 39, 487-501.

Caso, J. \& Hernández, L. (2010). Modelo explicativo del bajo rendimiento escolar: Un estudio con adolescentes mexicano [Explanatory model of low academic performance: A study with Mexican adolescents]. Revista Iberoamericana de Evaluación Educativa, 3(2), 145-159.

Castejón, J.L. \& Pérez A. M. (1998). Un modelo causal-explicativo sobre la influencia de las variables psicosociales en el rendimiento académico [A causal-explanatory model of the influence of psychosocial variables on academic performance]. Bordón, 50, 171185. 
De la Peña, V., Hernández, E. \& Rodríguez, F.J. (2003). Comportamiento asertivo y adaptación social: Adaptación de una escala de comportamiento asertivo (CABS) para escolares de enseñanza primaria (6-12 años) [Assertive behavior and social adjustment: Adaptation of a scale of assertive behavior (CABS) for students of primary education (6-12 years)]. Revista Electrónica de Metodología Aplicada, 8(2), 11-25.

Del Greco, L. (1983). The Del Greco Assertive Behavior Inventory. Journal of Behavioral Assessment, 5, 49-63.

Dietz, L., Jennings, K. \& Abrew, A. (2005). Social skill in self-assertive strategies of toddlers with depressed and nondepressed mothers. Journal of Genetic Psychology, 166 (1), 94-116.

Dodge, K.A., Bates, J. E. \& Pettit, G.S. (1990). Mechanisms in the cycle of violence. Science, 250, 1678-1683.

Dodge, K.A., Price, J.M., Coie, J.D. \& Christopoulos, C. (1990). On the development of aggressive dyadic relationships in boys peer groups. Human Development, 33, 260-270.

Fernández-C., A. \& Gutiérrez, M. E. (2009). Atención selectiva, ansiedad, sintomatología depresiva y rendimiento académico en adolescentes [Selective attention, anxiety, depressive symptomatology, and academic performance in adolescents]. Electronic Journal of Research in Educational Psychology, 17(7), 49-76.

García, C. (2005). Habilidades sociales, clima social familiar y rendimiento académico en estudiantes universitarios [Social skills, social family climate, and academic performance in university students]. Liberabit, 11, 63-74.

García, E. M. \& Magaz, A. (1994): ADCA-1. Escala de evaluación de la asertividad. [ADCA-1. Scale for the assessment of assertiveness]. Madrid, CEPE.

Garrido, E., Ortega, N., Escobar, J. \& García, R. (2010). Evaluación de la asertividad en estudiantes universitarios, con bajo rendimiento académico [Assessment of assertiveness in university students with poor academic performance]. Revista Científica Electrónica de Psicología, 9, 53-69.

Goldberg-Lillehoj, C., Spoth, R. y Trudeau, L. (2005). Assertiveness among young rural adolescents: Relationship to alcohol use. Journal of Child \& Adolescent Substance Abuse, 14(3), 39-68. 
González, A.E.M., Saura, C.J.I, Rodríguez, J.A.P \& Linares, V.R.L. (2010). The importance of friends and parents in health and academic performance. Electronic Journal of Reserach in Educational Psychology, 8(1), 111-138.

Harman, J., Hansen, C., Cochran, M. \& Lindsey, C. (2005). Liar, liar: internet faking but not frequency of use affects social skills, self-esteem, social anxiety, and aggression. CyberPsychology \& Behavior, 8(1), 1-6.

Jiménez, M.I. \& López, E. (2009). Inteligencia emocional y rendimiento escolar: Estado actual de la cuestión [Emotional intelligence and performance: Current state of the issue]. Revista Latinoamericana de Psicología, 1, 41, 69-79.

Kamalanabhan, T. J. (1998). Efficacy of a behavioural program for personality change an improvement in academic performance of school students. Journal of Psychological Researches, 32 (1-2), 93.

Marugán, M. (2000). Caracterización psicoeducativa del alumnado de educación compensatoria. [Psychoeducational description of compensatory education students]. I Hispanic Portuguese Congress of Psychology. Santiago de Compostela (Spain).

Marugán, M. \& Román, J.M. (2004). Asertividad y autoestima: variables claves en los alumnos con conductas problemáticas [Assertiveness and self-esteem: Key variables in students with problematic behaviors]. In M. I. Ruiz, F. Fajardo, \& A. V. Díez (Eds.), Aportaciones psicológicas y desarrollo difícil [Psychological contributions and difficult development] (pp. 455-464). Badajoz (Spain): Psicoex.

Michelson, L., Sugai, D.P., Wood, R.P. \& Kazdin, A.E. (1987). Social skills assessment and training with children. New York: Plenum Press. [Spanish translation: Las habilidades sociales en la Infancia. Evaluación y tratamiento. Barcelona, Martínez Roca, 1987].

Monjas, M. I. \& González, B. (Dir). (2000). Las habilidades sociales en el currículo [Social skills in the syllabus]. Madrid: Ministerio de Educación, Cultura y Deporte. Centro de Investigación y Documentación Educativa (CIDE).

Rajendran, R. \& Kaliappan, K. (1991). Efficacy of a behavioural programme in managing the academic stress and improving academic performance. Journal of Personality \& Clinical Studies, 6(2), 193.

Riso, W. (1988). Entrenamiento asertivo [Assertive training. Conceptual, evaluative, and interventional aspects]. Medellín: Rayuela. 
Rodríguez, F.J. \& Paíno, S.G. (1994). Violencia y desviación social: Bases y análisis para la intervención [Violence and social deviance: Basis and analysis for intervention]. Psicothema, 6, 229-244.

Salmivalli, C., Kaukiainen, A., Kaistaniemi, L. \& Lagerspetz, K.M.J (1999). Self-evaluated self-esteem, peer-evaluated self-esteem, and defensive egotism as predictors of adolescents' participation in bullying situations. Personality and Social Psychology Bulletin, 25(10), 1268-1278.

Stephanou, G. (2011). Emociones de los alumnos en la clase escolar: antecedentes sociocognitivos y rendimiento escolar [Student's emotions in the classroom: Sociocognitive antecedents and academic performance]. Electronic Journal of Research in Eucational Pychology, 9(1), 5-48.

Swanson, S. (2007). Assertiveness and aggressiveness as potential moderators of verbal behaviors following unsatisfactory service. Psychological Reports, 100(2), 467-475.

Trianes, M.V., Cardelle, M., Blanca, M.J. \& Muñoz, A. (2003). Contexto social, género y competencia social autoevaluada en alumnos andaluces de 11-12 años [Social context, gender, and self-rated social competence in 11-12-year-old Andalusian students]. Electronic Journal of Reserach in Educational Psychology, 1(2), 37-55.

Trianes, M., Blanca, M., García, B., Muñoz, A. \& Fernández, F. (2007). Assertive behaviour analysis in relation to adults: A relationship model between sources and components. Infancia y Aprendizaje, 30(2), 163-182.

Turner, B. (1992). Gender differences in old age in ratings of agression/assertiveness. Current Psychohogy, 11(2), 122-127.

Velásquez, C., Montgomery, U., Montero, M., Pomalaya, R., Dioses, A., Velásquez, N., Araki, R. \& Reynoso, D. (2008). Bienestar psicológico, asertividad y rendimiento académico en estudiantes universitarios sanmarquinos [Psychological well-being, assertiveness, and academic performance university students from San Marcos]. Revista de Investigación en Psicología, 11, 139-152.

Wilson, R.L. \& Hardgrave, B.C. (1995). Predicting graduate student success in an MBA program: Regression versus classification. Educational and Psychological Measurement, $55,186-195$. 
Wolpe, J. (1973). The practice of behavior therapy ( $2^{\text {nd }}$ ed.). Oxford, UK: Pergamo. [Spanish translation: La práctica de la terapia de conducta. México. Trillas,1977]. 